\title{
BENEDICT R. O'G. ANDERSON, 1936-2015: A BIBLIOGRAPHY
}

\section{The Editors}

\section{English-language Publications}

\section{Monographs}

Some Aspects of Indonesian Politics under the Japanese Occupation: 1944-1945. Ithaca: Cornell Modern Indonesia Project (pub. 29), 1961.

Mythology and the Tolerance of the Javanese. Ithaca: Cornell Modern Indonesia Project (pub. 37), 1965.

“The Pemuda Revolution: Indonesian Politics, 1945-1946." PhD thesis, Cornell University, 1967.

with Ruth T. McVey, asst. Frederick P. Bunnell. A Preliminary Analysis of the October 1, 1965, Coup in Indonesia. Ithaca: Cornell Modern Indonesia Project, Interim Reports (pub. 52), 1971; and London: Equinox Publishing, 2009.

Java in a Time of Revolution: Occupation and Resistance, 1944-1946. Ithaca: Cornell University Press, 1972; and London: Equinox Publishing, 2006.

Imagined Communities: Reflections on the Origin and Spread of Nationalism. London: Verso Books, 1983. Revised and expanded in 1991 and 2006.

Language and Power: Exploring Political Cultures in Indonesia. Ithaca: Cornell University Press, 1990.

The editors are grateful for the assistance of Lukas Ley in compiling an early version of this bibliography, and to Perry Anderson for his additions to and review of the material presented here. 
$142 \quad$ The Editors

The Spectre of Comparisons: Nationalism, Southeast Asia, and the World. London: Verso, 1998.

with Christopher Prendergast. Debating World Literature. London: Verso, 2004.

Under Three Flags: Anarchism and the Anti-Colonial Imagination. London: Verso, 2005. Republished as The Age of Globalization: Anarchists and the Anticolonial Imagination. London: Verso, 2013.

Why Counting Counts: A Study of Forms of Consciousness and Problems of Language in Noli Me Tangere and El Filibusterismo. Quezon City: Ateneo de Manila University, 2008.

The Fate of Rural Hell: Asceticism and Desire in Buddhist Thailand. New York: Seagull Books, 2012.

Exploration and Irony in Studies of Siam over Forty Years. Ithaca: Southeast Asia Program Publications, 2014.

A Life beyond Boundaries: A Memoir. London: Verso, 2016.

\section{Edited volumes}

with Mitsuo Nakamura and Mohammad Slamet. Religion and Social Ethos in Indonesia. Clayton: Monash University, 1977.

Violence and the State in Suharto's Indonesia. Ithaca: Southeast Asia Program Publications, 2000.

with Audrey Kahin. Interpreting Indonesian Politics: Thirteen Contributions to the Debate. Ithaca: Cornell Modern Indonesia Project, Interim Reports (pub. 62), 1982; and London: Equinox Publishing, 2009.

ed. and trans. with Ruchira C. Mendiones. In the Mirror: Literature and Politics in Siam in the American Era. Ithaca: Southeast Asia Program Publications, 1985.

with Christopher John Baker and Craig J. Reynolds. Pen \& Sail. Silkworm Books, 2005.

\section{Book chapters}

"Japan the Light of Asia," in Southeast Asia in World War II: Four Essays, ed. Josef Silverstein. New Haven: Yale University, Southeast Asia Studies, 1966.

"The Idea of Power in Javanese Culture," in Culture and Politics in Indonesia, ed. Clair Holt, 1-69. Ithaca: Cornell University Press, 1972.

"The Last Picture Show: Wayang Bèbèr," in Proceedings, Conference on Modern Indonesian Literature, ed. Jean Taylor et al., 33-81. Madison: University of Wisconsin Center for Southeast Asian Studies, 1974.

"Millenarianism and the Saminist Movement," in Religion and Social Ethos in Indonesia, ed. Benedict R. O'G. Anderson, Mitsuo Nakamura, and Mohammad Slamet, 48-61. Clayton: Monash University, 1977. 
"Religion and Politics in Indonesia since Independence," in Religion and Social Ethos in Indonesia, ed. Benedict Richard O'Gorman Anderson, Mitsuo Nakamura, and Mohammad Slamet, 21-32. Clayton: Monash University, 1977.

"Cartoons and Monuments: The Evolution of Political Communication under the New Order," in Political Power and Communications in Indonesia, ed. Karl D. Jackson and Lucian W. Pye, 282-321. Berkeley: University of California Press, 1978.

"Studies of the Thai State: The State of Thai Studies," in The Study of Thailand: Analysis of Knowledges, Approaches, and Prospects in Anthropology, Art, History, Economics, and Political Science, ed. Eliezer B. Ayal, 193-247. Athens: Ohio State University Center for International Studies, 1978.

"A Time of Darkness and a Time of Light: Transposition in Early Indonesian Nationalist Thought," in Perceptions of the Past in Southeast Asia, ASAA Southeast Asia Publications Series, ed. Anthony Reid and David Marr, 219-48. Singapore: Heinemann Educational Books, 1979.

"Indonesia and East Timor Critique," in Lawyers' Committee for International Human Rights, A Critique of the United States Department of State's Country Reports on Human Rights Practices for 1979. 271-81. New York: LCIHR, 1980.

"Statement Delivered to the Fourth Committee of the United Nations General Assembly on East Timor, October 20, 1980," in East Timor: Five Years after the Indonesian Invasion, ed. Jason Clay, 29-34. Cambridge: Cultural Survival, Occasional Paper No. 2, January 1981.

"Perspective and Method in American Research on Indonesia," in Interpreting Indonesian Politics: Thirteen Contributions to the Debate, ed. Benedict Anderson and Audrey Kahin, 69-83. Cornell Modern Indonesia Project, Interim Reports (pub. 62), 1982.

"Introduction," in Stubborn Survivors: Dissenting Essays on Peasants and Third World Development, ed. Rex Mortimer, vii-xvii. Clayton: Monash University, Centre of Southeast Asian Studies, 1984.

"Politics and Their Study in Southeast Asia," in Southeast Asian Studies: Options for the Future, ed. Ronald A. Morse, 42-45. Washington, DC: The Wilson Center, 1984.

"Sempah-Sumpah: The Politics of Language and Javanese Culture," in Change and Continuity in Southeast Asia, ed. Roger A. Long and Damaris A. Kirchofer, 15-57. Honolulu: University of Hawai'i at Manoa, Center for Asian and Pacific Studies, 1984.

“The Cultural Roots of Nationalism," in Politics and Ideology: A Reader, ed. James Donald and Stuart Hall. Philadelphia: Open University Press, 1986.

"Introduction" and "The State and Minorities in Indonesia," in Southeast Asian Tribal Groups and Ethnic Minorities, ed. Jason Clay, 1-15, 73-81. Cambridge: Cultural Survival, 1987. 
$144 \quad$ The Editors

"Afterword," in Ethnicities and Nations: Processes of Interethnic Relations in Latin America, Southeast Asia, and the Pacific, ed. Remo Guidieri, Francesco Pellizzi, and Stanley J. Tambiah, 402-6. Austin: University of Texas Press and Rothko Chapel, 1988.

"The Point of No Return," in Born in Fire: The Indonesian Struggle for Independence, ed. Colin Wild and Peter Carey, 86-91. Athens: Ohio University Press, 1988.

"Reading 'Revenge' by Ananta Toer (1978-1982)," in Writing on the Tongue, 33rd edition of Michigan Papers on South and Southeast Asia, ed. A. L. Becker, 1394. Ann Arbor: Center for South and Southeast Asian Studies, University of Michigan, 1989.

"Apprehensions of Time," in Popular Fiction: Technology, Ideology, Production, Reading, ed. Tony Bennett. London and New York: Routledge, 1990.

"Authoritarianism: Indonesia," "Political Culture in Indonesia," and "The Political Role of the Military in Indonesia," in Asia: Case Studies in the Social Sciences, ed. Myron L. Cohen, 311-48. Armonk: M. E. Sharpe, 1992.

"The Changing Ecology of Southeast Asian Studies in the United States, 1950-1990," in Southeast Asian Studies in the Balance: Reflections from America, ed. Charles Hirschman, Charles F. Keyes, and Karl Hutterer, 25-40. Ann Arbor: Association for Asian Studies, 1992.

"John Smail and Cornell: Reminiscences," in Autonomous Histories, Particular Truths, ed. Laurie Sears, 247-50. Madison: University of Wisconsin, Center for Southeast Asian Studies, 1993.

"Nationalism," in The Oxford Companion to the Politics of the World, ed. Joel Kireger, 61419. New York: Oxford University Press, 1993.

"Rewinding 'Back to the Future': The Left and Constitutional Democracy," in Democracy in Indonesia, 1950s and 1990s, ed. David Bourchier and John Legge, 128-42. Clayton: Monash University Papers on Southeast Asia, 1994.

"Cacique Democracy in the Philippines," in Discrepant Histories: Translocal Essays on Filipino Cultures, ed. Vicente L. Rafael, 3-47. Philadelphia: Temple University Press, 1995.

"East Timor and Indonesia: Some Implications," in East Timor at the Crossroads: The Forging of a Nation, ed. Peter Carey and G. Carter Bentley, 137-47. London: Cassell, 1995.

“'Bullshit!' She Said: The Happy, Modern, Sexy, Indonesian Married Woman as Transsexual," in Fantasizing the Feminine in Indonesia, ed. Laurie J. Sears, 270-94. Durham: Duke University Press, 1996.

"Colonial Language Policies in Indonesia and the Philippines: A Contrast in Intended Aims and Unintended Consequences," in Text and Nation, ed. Laura GarciaMoreno and Peter C. Pfeiffer, 17-27. Columbia: Camden House, 1996.

"Elections and Participation in Three Southeast Asian Countries," in The Politics of Elections in Southeast Asia, ed. Robert Taylor, 12-23. Cambridge: Woodrow Wilson Center Press and Cambridge University Press, 1996. 
"Introduction," in Mapping the Nation, ed. Gopal Balakrishnan, 1-16. London and New York: Verso, 1996.

"Language, Fantasy, Revolution: Java 1900-1950," in Making Indonesia: Essays on Modern Indonesia in Honor of George McT. Kahin, ed. Daniel S. Lev and Ruth McVey, 2640. Ithaca: Southeast Asia Program Publications, 1996.

"Nationalism, Identity, and the World-In-Motion: On the Logics of Seriality," in Cosmopolitics, ed. Pheng Cheah and Bruce Robbins, 117-33. Minneapolis: University of Minnesota Press, 1998.

"Introduction" in Pramoedya Ananta Toer, Tales from Djakarta: Caricatures of Circumstances and Their Human Beings, 11-15. Ithaca: Cornell University Press, 1999.

"The Goodness of Nations," in Nation and Religion: Perspectives on Europe and Asia, ed. Peter van der Veur and Hartmut Lehmann, 197-203. Princeton: Princeton University Press, 1999.

with Carol Hau, "Introduction," in Carlos Bulosan, All the Conspirators, vii-xxvii. Manila: Anvil, 1999.

"Western Nationalism and Eastern Nationalism: Is there a Difference that Matters?" in Conference Papers, International Conference on World Civilizations in the New Century: Trends and Challenges, 1-8. Taipei: Institute for National Policy Research, 2000.

"Introduction," in Violence and the State in Suharto's Indonesia, ed. Benedict R. O'G. Anderson, 9-19. Ithaca: Southeast Asia Program Publications, 2001.

"Staging Antimodernism in the Age of High Capitalists Nationalism," in Antimodernism and the Artistic Experience: Policing the Boundaries of Modernism, ed. Lynda Jessup, 97-103. Toronto: University of Toronto Press, 2001.

"Responses," afterword in Grounds of Comparison: Around the Work of Benedict Anderson, ed. Jonathan Culler and Pheng Cheah (New York: Routledge, 2003), 225-45.

"Nationalism and Cultural Survival in Our Time: A Sketch," in At Risk of Being Heard: Identity, Indigenous Rights, and Postcolonial States, ed. Dean Bartholomew and Jerome Levi, 165-90. Ann Arbor: The University of Michigan Press, 2003.

"Cracking the Myths of Nation-ness: Indonesia after the Fall of Suharto," in The Shifting Foundations of Modern Nation-States: Realignments of Belonging, ed. Sima Godfrey and Frank Unger, 149-61. Toronto: University of Toronto Press, 2004.

"Imagined Communities," in Nations and Nationalism: A Reader, ed. Philip Spencer and Howard Wollman. New Brunswick: Rutgers University Press, 2005.

"Nationalism, Identity, and the World-in-Motion: On the Logics of Seriality," in Cosmopolitics: Thinking and Feeling Beyond the Nation, ed. Pheng Cheah and Bruce Robbins. Minneapolis: University of Minnesota Press, 2005.

"Meeting the Artist," in Ida bagus Made: The Art of Devotion, ed. Kaja McGowan, Adrian Vickers, and Soemantri Widagdo, 7-8. Ubud: Ratna Wartha Foundation, 2008. 
$146 \quad$ The Editors

"The Strange Story of a Strange Beast: Receptions in Thailand of Apichatpong Weerasethakul's Sat Pralaat," in Apichatpong Weerasethakul, ed. James Quandt, 158-77. Vienna: SYNEMA, 2009.

"The Nation and the Origins of National Consciousness," in The Ethnicity Reader: Nationalism, Multiculturalism and Migration, ed. Montserrat Guibernaut and John Rex, 43-51, 2nd ed. Boston: Polity, 2010.

"Foreword," in Thomas S. Mullaney, Coming to Terms with the Nation: Ethnic Classification in China. Berkeley: University of California Press, 2011.

"Impunity," in Killer Images: Documentary Film, Memory, and the Performance of Violence, ed. Joram Ten Brink and Joshua Oppenheimer. New York: Wallflower, 2012.

"Colonial Cosmopolitanism," in Social Science and Knowledge in a Globalising World, ed. Zawawi Ibrahim, 371-88. Petaling Jaya: Persatuan Sains Sosial Malaysia, 2012.

"Public Intellectuals," in Asia: Identity, Vision and Position, ed. Khoo Boo Teik and Tatsuya Tanami, 44-53. Tokyo: The Nippon Foundation, 2012.

\section{Articles, Essays, Lectures, and Newspaper Features}

"Government and Politics" [Indonesia], Encyclopedia Americana. 1963.

“Malaysia and Indonesia," New Left Review 28 (November 1964): 4-32; published under the nom de plume of Robert Curtis.

“Indonesia: United against Progress," Current History 48, 282 (1965): 75-81.

“The Languages of Indonesian Politics,” Indonesia 1 (April 1966): 89-116.

“The Problem of Rice," Indonesia 2 (October 1966): 77-82 (introduction to translated material).

"Diachronic Field-Notes on the Coronation Anniversary at the Kraton Surakarta Held on December 18, 1963," Indonesia 3 (April 1967): 62-71.

“Indonesia's Uncertain Future," Current History 57, 340 (December 1969): 355-60.

“In Memoriam: Soe Hok-Gie," Indonesia 9 (April 1970): 225-27.

"Current Data on the Indonesian Military Elite after the Reorganization of 1969-1970," Indonesia 10 (October 1970): 195-208.

“In Memoriam: Claire Holt," Indonesia 10 (October 1970): 191-94.

"Cultural Factors in the Indonesian Revolution," Asia 20 (Winter 1971-72): 48-65.

"Current Data on the Indonesian Military Elite," Indonesia 15 (April 1973): 187-97.

"Notes on Contemporary Indonesian Political Communication," Indonesia 16 (October 1973): 39-80. Republished as MIT monograph in 1976.

“Current Data on the Indonesian Military Elite," Indonesia 18 (October 1974): 153-67.

"Prepared Testimony on Human Rights in Indonesia," in Human Rights in Indonesia and the Philippines. Washington, D.C.: Government Printing Office, 1976. 72-80. 
Letter, “Thailand: The New Dictators,” New York Times, November 2, 1976.

“Current Data on the Indonesian Military Elite," Indonesia 23 (April 1977): 175-90.

"Withdrawal Symptoms: Social and Cultural Aspects of the October 6 Coup," Bulletin of Concerned Asian Scholars 9 (1977): 13-30.

with Ruth McVey, "What Happened in Indonesia?" New York Review of Books XXV (June 1, 1978): 40-42.

“The Last Days of Indonesia's Suharto?” Southeast Asia Chronicle 63 (July-August 1978): 2-17.

“Current Data on the Indonesian Military Elite," Indonesia 26 (October 1978): 159-77.

"U.S. Policy on Human Rights and Military Assistance to Indonesia," in Foreign Assistance Legislation in Fiscal Year 1979, Part 4. Washington, DC: GPO, 1978. 27 46.

"Defence of the Student Movement: Documents from Recent Trials," Indonesia 27 (April 1979): 1-32.

"A Critique of the 1979 State Department Report on Human Rights in Indonesia," Tapol-USA 18-19 (April-May 1979): 1, 14-16.

"Prepared Testimony on Human Rights in Indonesia and East Timor," in Human Rights in Asia: Noncommunist Countries. Washington, DC: GPO, 1980. 231-62; 275-77.

“Current Data on the Indonesian Military Elite," Indonesia 29 (April 1980): 155-75.

“Looking Back,” The Wilson Quarterly 5, 2 (Spring 1981): 113-25.

"Critique of Professor Emmerson's Analysis," in Indonesia in the 1980s: Proceedings, U.S. State Department Conference, May 4, 1981. Washington, DC: US Department of State, 1981.

“The Suluk Gațoloco, Part One," Indonesia 32 (October 1981): 109-50.

“The Suluk Gațoloco, Part Two,” Indonesia 33 (April 1982): 31-88.

"Sembah-Sumpah [Courtesy and Curses]: The Politics of Language and Javanese Culture," Change and Continuity in Southeast Asia (1982): 15-58.

“Current Data on the Indonesian Military Elite," Indonesia 33 (April 1982): 129-48.

"Old State, New Society: Indonesia's New Order in Comparative Historical Perspective," Journal of Asian Studies 42, 3 (1983): 477-96.

"Pramoedya Ananta Toer," Encyclopeadia of World Literature in the 20th Century, volume 3, 586-88. New York: Frederick Ungar, 1983.

"Current Data on the Indonesian Military Elite," Indonesia 36 (October 1983): 99-134.

“Current Data on the Indonesian Military Elite," Indonesia 37 (April 1984): 145-69.

“Current Data on the Indonesian Military Elite," Indonesia 40 (October 1985): 131-64.

“Nationalism-Catalyst or Trap?” Times Literary Supplement, March 28, 1986: 133.

“Report from East Java,” Indonesia 41 (April 1986): 134-49. 
$148 \quad$ The Editors

“Narrating the Nation," Times Literary Supplement, June 13, 1986: 659.

“James Fenton's Slideshow,” New Left Review 158 (July-August 1986): 81-90.

"Statement delivered on August 15, 1986, to the Fourth Committee (Decolonization) of the U.N. General Assembly on the Situation in East Timor," Indonesia 42 (October 1986): 129-42.

“Old Corruption," London Review of Books 9, 3 (February 5, 1987): 3-6.

“How Did the Generals Die?” Indonesia 43 (April 1987): 109-34.

“Time is Running Short for Suharto's Regime,” Newsday, June 17, 1987: 85.

"Current Data on the Indonesian Military Elite," Indonesia 45 (April 1988): 137-60.

"Cacique Democracy in the Philippines: Origins and Dreams," New Left Review, 169 (May-June 1988): 3-31. Reprinted in Vicente Rafael, ed., Discrepant Histories: Translocal Essays on Filipino Culture. Philadelphia: Temple University Press, 1995. 3-47.

"The Implications of Political Killings in Modern-Day Thailand," Kasarinlan 4, 1 (Third Quarter, 1988): 21-30.

"Current Data on the Indonesian Military Elite," Indonesia 48 (October 1989): 65-96.

"Murder and Progress in Modern Siam," New Left Review 181 (May-June 1990): 33-48.

“Language, Fantasy, Revolution: Java 1900-1945," Prisma 50 (September 1990): 25-39.

“Looking Back," Indonesia 50 (October 1990): 1-3.

"Long-Distance Nationalism: World Capitalism and the Rise of Identity Politics," The Wertheim Lecture, University of Amsterdam, Centre for Asian Studies, 1992, $1-14$.

“The New World Disorder," 24 Hours Special Supplement (February 1992; the full text of the six-lecture series broadcast on Radio National's Indian Pacific from January 4 to February 8, 1992): 40-46 (Anderson's segment is based on a talk recorded by the Australian Broadcasting Corporation in Ithaca, NY, on December 5, 1991). Revised and expanded in New Left Review 193 (May-June 1992): 3-13.

with Takashi Shiraishi, "Current Data on the Indonesian Military Elite," Indonesia 53 (April 1992): 94-136.

"Charting Imagined Borders," The Book Press 2, 3 (April 1992): 1, 18-20.

"On Being Valiant-for-Truth," Asian Studies Review (journal of the Asian Studies Association of Australia) 16, 1 (July 1992): 53-60.

"Thailand, the Philippines, and Indonesia: What Price Democracy?" 24 Hours (September 1992): 2-6.

"The 'Noli' Bowdlerized" [in two parts], The Manila Chronicle, September 26-October 2 and October 3-9, 1992.

“Two Massacres: Dili-Bangkok," Southeast Asian Network Bulletin 1 (December 1992): $19-20$. 
“Imagining 'East Timor,"” Arena (April-May 1993): 23-27.

"Radicalism after Communism in Thailand and Indonesia," New Left Review 202 (December 1993): 3-14.

with Peter Wortsman, "Réplica, Aura, and Late Nationalist Imaginings," Qui Parle 7, 1 (Fall/Winter 1993): 1-21.

"Exodus," Critical Inquiry 20, 2 (1994): 314-27. Reprinted as "Hard to Imagine: A Puzzle in the History of Philippine Nationalism," in Cultures and Texts: Representations of Philippine Society, ed. Raul Pertierra and Eduardo F. Ugarte, 80-118. Quezon City: University of Philippines Press, 1994.

"Hard to Imagine: A Puzzle in the History of Philippine Nationalism," Review of Indonesia and Malaysian Affairs 28, 1 (Winter 1994): 59-85.

“End Indonesia’s Imperialist Rule," New York Times, November 13, 1994.

Contribution to "Nationalism: The Modern Janus," Ideas [Toronto/CBC], May 3-17, 1993: 1-33.

with Takashi Shiraishi, "Current Data on the Indonesian Military Elite," Indonesia 56 (October 1993): 119-52.

"Elections and Participation in Three Southeast Asian Countries," The Politics of Elections in Southeast Asia (1996): 12-33.

"Scholarship on Indonesia and Raison d'Etat: Personal Experience," Indonesia 62 (October 1996): 1-18.

“The Grammars of Modern Identity,” Macalaster International 4 (Spring 1997): 22-23.

"Last of the Southeast Asian Cold War Rulers," The Nation [Bangkok], March 4, 1998: $4-5$.

"From Miracle to Crash," London Review of Books 20, 8 (April 16, 1998): 3-7.

"Soaking in Luang Prabang," London Review of Books 20, 12 (June 18, 1998): 22-24.

with Takashi Shiraishi and Douglas Kammen, "Current Data on the Indonesian Military Elite,” Indonesia 67 (April 1999): 133-62.

"Indonesian Nationalism Today and in the Future," Indonesia 67 (April 1999): 1-12.

"Indonesian Nationalism Today and in the Future," New Left Review 235 (June 1999): $3-17$.

"A Language Learned in Java: A Collector's View of his Masks," Bulletin of the Southeast Asia Program (Cornell University), 1999. 6-11.

"Indonesia Statistik: Surat buat Para Pembaca," Indonesia 69 (April 2000): 173-75.

with Stanley J. O'Connor and Thak Chaloemtiarana, "George Kahin, 1918-2000," Indonesia 69 (April 2000): 5-8.

"Petrus Dadi Ratu: Killer Becomes King," Indonesia 70 (October 2000): 1-7.

“The Rooster's Egg: Pioneering World-Folklore in the Philippines," New Left Review 2 (2000): 47. 
“Petrus Dadi Ratu," New Left Review 3 (2000): 7-15.

"Reimaging Asia," Kyoto Journal 45 (2000): 22-27.

"George McT. Kahin," Bulletin of the Southeast Asia Program (Cornell University), 2001: $2-3$.

"To What Can Late Eighteenth-Century French, British, and American Anxieties Be Compared?" The American Historical Review 106, 4 (October 2001): 1281-89.

"Western Nationalism and Eastern Nationalism," New Left Review 9 (June 2001): 3142.

"Memory and Forgetting: Nationalism in Indonesia and Taiwan-Even in Japan!" Journal of Kyoto Seika University 21 (2001): 74-85. Based on a lecture delivered for the Faculty of Humanities, Kyoto Seika University, June 13, 2000.

"Long Live the Nation!" Biblio [India], March-April 2002: 22-25.

“Twilight Dogs-Jangled Nerves," Indonesia 73 (April 2002): 129-44.

"Bung Karno and the Fossilization of Soekarno's Thought," Indonesia 74 (October 2002): 1-19.

"Lomond and Gracedieu," Penang Heritage Trust Newsletter, 2003: 17-19.

"Forms of Consciousness in Noli Me Tangere," Philippine Studies 51, 4 (2003): 505-29.

"Selective Kinship: A Family History, with Omissions," Dublin Review 10 (Spring 2003): 5-29.

“Nitroglycerine in the Pomegranate," New Left Review 27 (June 2004): 99-118.

"In the World-Shadow of Bismarck and Nobel," New Left Review 28 (August 2004): 85129.

"Jupiter Hill," New Left Review 29 (October 2004): 91-120.

“The World of Sergeant-Major Bungkus," Indonesia 78 (October 2004): 1-6.

"The World of Sergeant-Major Bungkus: Two Interviews with Benedict Anderson and Arief Djati," Indonesia 78 (October 2004): 7-60.

“Sam's Club," Artforum International, December 2004.

"First Love: The Opening of Soetjipto's Djalan Sampoerna," Indonesia 82 (October 2006): 39-74.

"Forms of Consciousness in 'El Filibusterismo,"” Philippine Studies 54, 3 (2006): 31556.

"Into the Whirlpool: The Second Part of Soetjipto's Djalan Sampoerna," Indonesia 84 (October 2007): 97-126.

"Cutting History off at the Pass," Diliman Review 55 (2008): 1-4.

"Exit Suharto," New Left Review 50 (April 2008): 27-59.

"Madman Lynched, Icon Cloned, Rancour Remains," The Drawbridge 9 (Summer 2008): 3. 
“Thak," Bulletin of the Southeast Asia Program (Cornell University), 2010: 4-7.

"VOICES-Few Intellectuals in Court of Public Opinion," Bangkok Post, June 28, 2010.

“Ulama Hill,” Indonesia 91 (April 2011): 105-12.

"Letters, Secrecy, and the Information Age: The Trajectory of Historiography in Southeast Asia." Ninth Frank H. Golay lecture, Cornell University, October 25, 2012. Transcript published in Bulletin of the Southeast Asia Program (Cornell University), Fall 2013: 13-17.

“The Unrewarded," New Left Review 80 (April 2013): 99-108.

"Origins of Indonesia [the journal] and the Sustenance of Its Excellence, 1966-2015," Indonesia 100 (October 2015): 5-8.

"Frameworks of Comparison," London Review of Books 38, 2 (January 21, 2016): 15-18.

"Riddles of Yellow and Red," New Left Review 97 (January-February 2016), 7-20.

\section{Book Reviews}

“Bungas Emas," New Left Review I/31 (May-June 1965), 102-4; published under the nom de plume of Robert Curtis.

Review of Jusus Maria van der Kroef, The Communist Party of Indonesia, in The China Quarterly 28 (October-December 1966): 141-43.

Review of Hughes, Indonesian Upheaval, in Far Eastern Economic Review, March 14, 1968.

Review of Pluvier, South-East Asia from Colonialism to Independence, in Journal of Asian Studies 35, 1 (1975): 171-73.

Review of Ricklefs, Jogjakarta under Sultan Mangkubumi, 1749-1792, in Journal of Asian Studies 36, 3 (1977): 196-97.

Review of Scott, The Moral Economy of the Peasant: Rebellion and Subsistence in Southeast Asia, in Journal of Asian Studies 37, 1 (1977): 172-74.

Review of Smit, De Dekolonisatie van Indonesië: Feitan en Beschouwingen, in Pacific Affairs 50, 3 (Fall 1977): 547-49.

Review of Widjanarko, Karni, and Dake, The Devious Dalang: Sukarno and the So-Called Untung-Putsch: Eye-Witness Report, ed. Karni, in American Political Science Review 71, 4 (December 1977): 1704-5.

Review of Reid, The Blood of the People, in Pacific Affairs 53, 4 (Winter 1980-81): 780-82.

Review of Rendra, The Struggle of the Naga Tribe: A Play, in Journal of Asian Studies 40, 2 (1981): 428-30.

Review of Tichelman, The Social Evolution of Indonesia: The Asiatic Mode of Production and Its Legacy, in Pacific Affairs 54, 3 (Fall 1981): 362-64.

Review of Geertz, Negara: The Theater State in Nineteenth Century Bali, in American Historical Review 86, 5 (December 1981): 1137. 
$152 \quad$ The Editors

Review of Mackie, ed., Indonesia: The Making of a Nation, Volume 3, in Asian Studies Association of Australia Review 6, 2 (December 1982): 78-81.

Review of McCoy, ed., Southeast Asia under Japanese Occupation, in Journal of Asian Studies 42, 2 (1983): 456-57.

Review of King, Interest Groups and Political Linkage in Indonesia, 1900-1965, in Pacific Affairs 56, 2 (Summer 1983): 378-80.

Review of Hardjapranata, Pijar2 Api, in World Literature Today 58, 3 (Summer 1984): 474-75.

Review of Zawawi Imron, Bulan Tertusuk Lalang, in World Literature Today 58, 3 (Summer 1984): 475-76.

Review of Errington, Manners and Meaning in West Sumatra: The Social Context of Consciousness, in Journal of Asian Studies 45, 1 (1985): 192-94.

Review of Achdiat Kartamihardja, Keretakan dan Ketegangan, in World Literature Today 59, 2 (Spring 1985): 317-18.

Review of I Gusti Ngurah Putu Wijaya, Nyali, in World Literature Today 59, 3 (Summer 1985): 488.

Review of Errington, Language and Social Change in Java: Linguistic Reflexes of Modernization in a Traditional Royal Polity, in Journal of Asian Studies 45, 2 (1986): 446-48.

Review of Raillon, Les Etudiants Indonésiens et l'Ordre Nouveau. Politique et Idéologie Du Mahasiswa Indonesia (1966-1974), in Pacific Affairs 59, 3 (1986): 541-42.

Review of Rubenstein, The Honey Tree Song: Poems and Chants of Sarawak Dayaks, in World Literature Today 60, 3 (Summer 1986): 522.

Review of Ewe Paik Leong, Lion City Contract, in World Literature Today 60, 4 (Autumn 1986): 688 .

Review of Smithies, A Busy Week: Tales from Today's Thailand, in World Literature Today 60, 4 (Autumn 1986): 692.

Review of Penders and Sundhaussen, Abdul Haris Nasution: A Political Biography, in Journal of Asian Studies 46, 1 (1987): 217-19.

Review of Olsen and Jurika, eds., The Armed Forces in Contemporary Asian Societies, in Journal of Asian Studies 46, 3 (1987): 624-25.

Review of Bonner, Waltzing with a Dictator, in The Boston Globe (June 14, 1987): B11.

Review of Khadijah Hashim, When the White Dove Flies Again, in World Literature Today 61, 3 (Summer 1987): 493.

Review of Foulcher, Social Commitment in Literature and the Arts: The Indonesian "Institute of People's Culture" 1950-1965, in Pacific Affairs 61, 1 (1988): 196-98.

Review of Larson, Prelude to Revolution: Palaces and Politics in Surakarta, 1912-1942, in Journal of Asian Studies 47, 3 (1988): 706-7.

"Criollismo." Review of Canny and Pagden, eds, Colonial Identity in the Atlantic World, 1500-1800, in London Review of Books 10, 2 (January 1988): 5-6. 
Review of Keeler, Javanese Shadow Plays, Javanese Selves, in World Literature Today 62, 2 (Spring 1988): 334-35.

Review of Phillips, Modern Thai Literature, with an Ethnographic Interpretation, in World Literature Today 62, 2 (Spring 1988): 338.

Review of Seagrave, The Marcos Dynasty, in The Boston Globe, December 11, 1988.

"Machine Dreams." Review of Adas, Machines as the Measure of Men, in The New Republic, April 9, 1990: 37-39.

Review of Hart et al., eds., Agrarian Transformations: Local Processes and the State in Southeast Asia, in Comparative Studies in Society and History 33, 4 (1991): 800-801.

Review of Pramoedya Ananta Toer, The Fugitive, in World Literature Today 65, 2 (Spring 1991): 367.

"Four Blind Mice." Review of Staniland, American Intellectuals and African Nationalists, 1955-1970, in The New Republic, September 16, 1991.

"Creole Zones." Review of Brading, The First America: The Spanish Monarchy, Creole Patriots, and the Liberal State (1492-1878), in The London Review of Books, November 7, 1991: 10-11.

"Why Something Is Rotten in the Nation-State." Review of Davidson, The Black Man's Burden: Africa and the Curse of the Nation State, in The Guardian (November 3, 1992).

Review of Lubis, Tiger! in World Literature Today 67, 1 (1993): 69-85.

"Gravel in Jakarta's Shoes." Review of Cox and Carey, Generations of Resistance, in London Review of Books 17, 20 (1995): 3-5.

"Djojo on the Corner." Review of Geertz, After the Fact: Two Countries, Four Decades, One Anthropologist, in London Review of Books 17, 16 (August 1995): 19-20.

"Ice Empire and Ice Hockey: Two Fin de Siecle Dreams." Review of Kapucinski, Imperium; and Ignatieff, Blood and Belonging: Journeys into the New Nationalism, in New Left Review, 214 (December 1995): 146-50.

"Noli in the Nineties," Conjecture [Manila], December 1995: 13.

Review of Malkki, Purity and Exile: Violence, Memory, and National Cosmology among the Hutu Refugees in Tanzania, in Contemporary Sociology 25, 6 (November 1996): 773-4.

"First Filipino." Review of Rizal, Noli Me Tangere, trans. Soledad Lacson-Locsin, in London Review of Books 19, 20 (October 16, 1997): 22-23.

"Sam's Club." Review of Ross and Ross, eds., Anti-Americanism; and Lebovics, Bringing the Empire Back Home: France in the Global Age, in Bookforum 11, 4 (December 2004): 22-23

"A Greater Netherlands." Review of James and Schrauwers, eds., Anthropologists Explore Indonesia and South Africa (special Issue of Itinerario), in Journal of Southern African Studies 32, 2 (2006): 419-21. 
$154 \quad$ The Editors

“Becoming Dutch, Staying Indo.” Review of Lizzy Van Leeuwen, Ons Indisch Erfgoed: Zestig Jaar Strijd om Cultuur en Identiteit [Our Indies heritage: Sixty years of struggle for culture and identity], in Inside Indonesia 103 (January-March 2011).

Review, with Leslie Dwyer, of Steedly, Rifle Reports: A Story of Indonesian Independence, in Sojourn: Journal of Social Issues in Southeast Asia 30, 3 (2015): 860-76.

\section{Translations into English}

Indonesia in the Modern World. New Delhi: Congress for Cultural Freedom, 1961. Translation of Sutan Takdir Alisjahbana, Indonesia dalam masa peralihan. Reprinted as Indonesia: Social and Cultural Revolution. London: Oxford University Press, 1966.

"Sensation at the Top of a Coconut Tree," in A Treasury of Modern Asian Stories, ed, Daniel L. Milton. New York: New American Library, 1961. Translation of Achdiat Kartamihardja, "Sensasi diatas pohon kelapa."

"The Problem of Rice: Stenographic Notes on the Fourth Session of the Sanyo Kaigi, January 8, 2605, 10:00 A.M." [with introduction and notes], Indonesia 2 (October 1966): 77-123, esp. 82-123.

Our Struggle. Translation, with introductory essay, of Sutan Sjahrir, Perdjoenangan Kita. Ithaca: Cornell Modern Indonesia Project (pub. 44), 1967.

with Mrs. S. U. Nababan, of Idrus, “Surabaja,” Indonesia 5 (April 1968): 1-28.

with Elizabeth Graves, Report from Banaran. Ithaca: Cornell Modern Indonesia Project (pub. 55), 1972. Translation of Tahi Bonar Simatupang, Laporan dari Banaran.

with Toenggoel Siagian, of H. Mohammed Said, "What Was the 'Social Revolution of 1946' in East Sumatra?” Indonesia 15 (April 1973): 145-86.

"Revolution and Social Tensions in Surakarta 1945-1950," Indonesia 17 (April 1974): 99-112. Translation of Soejatno, Revolusi dan ketegangan2 sosial di Surakarta, 1945-1950.

Analysis of Responsibility. Melbourne: The Works Co-operative, 1974. Translation of Sudisman, Uraian Tanggungdjawab.

“M.M.M.: Five Animal Tales," Indonesia 25 (April 1978): 81-114. Translation of Prijana Winduwinata, M. M. M.

“The White Book of the 1978 Student's Struggle," Indonesia 25 (April 1978): 151-82. Translation of Buku Putih Perjuangan Mahasiswa 1978.

“Revenge," Indonesia 26 (October 1978): 43-62. Translation of Pramoedya Ananta Toer, Dendam.

“On Musso’s Return,” Soerjono, Indonesia 29 (April 1980): 59-90.

“On Musso’s Return, Addendum,” Indonesia 30 (October 1980): 163-64. 
Break the Chains of Oppression of the Indonesian People. Ithaca: Cornell Modern Indonesia Project (pub. 59), 1981. Translation of Heri Akhmadi, Mendobrak Belenggu Penindasan Rakyat Indonesia.

"Mrs. Veterinary Doctor Suharko (Nyonya Dokterhewan Suharko)," with trans. Foreword, Indonesia 34 (October 1982): 65-74. Translation of Pramoedya Ananta Toer, "Nyonya Dokterhewan Suharko."

"Perburuan 1950 and Keluarga Gerilya 1950," Indonesia 36 (October 1983): 25-48. Translation of Pramoedya Ananta Toer, Perburuan and Keluarga Gerilya.

“Am I PKI or Non-PKI?” Indonesia 40 (October 1985): 37-56, with trans. Afterword. Translation of Pipit Rochijat.

"The 'Roh' of the System: On the Unification of Meaning and Expression in a Contemporary Indonesian Novel," Indonesia 40 (October 1985): 75-88. Translation of Amrih Widodo.

trans., "The Syam Kuk of Angkor Wat's Bas-Reliefs," in Bernard-Philippe Groslie, Syam Kuk, 2002, 83-97. Translation of Bernard-Philippe Groslier, "Les Syam Kuk des bas-reliefs d'Angkor Vat."

trans., "Graffiti in the Toilet," with trans. Introduction, Indonesia 86 (October 2008): 55-62. Translation of Eka Kurniawan, "Coret-coret di Toilet."

trans., "The Otter Amulet (Jimat Séro)," Indonesia 89 (April 2010): 93-99. Translation of Eka Kurniawan, "Jimat Séro."

trans., “'Either One is a Fascist or One is Not': The Indies' National-Socialist Movement, The Imperial Dream, and Mussert's Colonial Milch Cow," Indonesia 92 (October 2011): 43-58. Translation of Tessel Pollmann, "Men is fascist of men is het niet': De Indische NSB als imperiale droom en koloniale melkkoe.”

\section{Non-English Published Work}

Gagasan tentang kekuasaan di dalam kebudayaan Jawa. Yogyakarta: Untuk Kalangan Sendiri, 1972.

"Sembah-Sumpah: Politik Bahasa dan Kebudayaan Jawa," Prisma XI, 11 (November 1981): 69-96.

"Samphat: khuy kap Bennedik Aendoesan (ruang ruam ruangsan samai mai)," Lok Nangsue 5, 6 (March 1982): 50-65.

"Saat yang menentukan," in Gelora Api Revolusi, ed. Colin Wild and Peter Carey. Jakarta: BBC and Gramedia, 1986. 96-102.

"Dinosaurus Hidup di Jalan Raya" [A Live Dinosaur on the Streets], Editor, October 27, 1990: 26-27.

“Buset! Mustahil Gatokaca Kawin dengan Dewi Pregiwati” [Shit! No Way Gatokaca Will Marry Princess Pregiwati], Editor, November 17, 1990: 98-99.

"Mengharap Petruk Jadi Raja?" [Hoping Petrus will Become King?], Editor, December 8, 1990: 26-27. Reprinted in Arah 4 (1990-91): 13-16. 
“Adegan Ranjang Campur-Aduk" [Hybrid Sex Scene], Editor, January 5, 1991: 24-25.

"Mantra 'Andaikata' Dewi Sejarah" [The Goddess of History's Mantra: Just Suppose...], Editor, January 12, 1991: 92-93.

“Forum Demokrasi di Kalangan Dedemit," Berita Tanah Air, May 1, 1992.

“A aposta de Jacarta em Timor está perdida," Público [Lisbon], May 23, 1992: 17.

“Timor-Um Falhanço Indonésio," O Comércio do Porto [Oporto], June 1, 1992: 5.

"Introduction," in Thanet Aphornsuway, Pok Pleuk Prachathipatai nai Amerika [Peeling Off the Skin of Democracy in America]. Bangkok: Sayam, 1992. 10-13.

"Isyu," Berita Tanah Air 13, 5-6 (May-June 1994): 1-3.

"Kawanku Kenji" [My Friend Kenji], in Jikan no taba o himotoite: Tsuitoshu Tsuchiya Kenji [Untying the Sheaves of Time: To the Memory of Kenji Tsuchiya]. Kyoto: Tsuchiya Kenji Tsuitoshu Kanko-kai, 1996. 589-91.

"Pengaruh Mental Jawa Priyayi Sangat Nampak" [The Influence of the Javanese Bureaucratic Mentality is Very Visible], Kanaka 11, 4 (1996): 16-18.

"Recensement et politique en Asie du Sud-est," Genèses 26 (April 1997): 55-76.

"As promesas do Estado-naçao para o inincio do século" [The Promises of the NationState at the Beginning of the Century], in A crise dos paradigmas en ciéncias socais $e$ os desafios para o século XXI, ed. Marco Pamploma, et. al. Rio de Janeiro: Contrapunto, 1999. 155-79.

"Surat buat para pembatja" [Letter for Readers], Tempo [Millenium Edition], January 16, 2000: 90-91. Reprinted in Indonesia 69 (April 2000): 173-75, citation above.

"Petrus Mendjadi Ratu," Tempo, April 10-16, 2000: 51-54. Reprinted as supplementary introduction to Abdul Latief, Pledoi Kol. A. Latief, Suharto Terlibat G30S. Jakarta: Institut Arus Informasi, 2000.

"El huevo del gallo. Un pionero del folclore mundial en filipinas," New Left Review [Spanish version] 3 (July-August 2000): 77-89.

"El malhadado país," New Left Review [Spanish version] 5 (November-December 2000): 149-72.

"O tempo está do nosso lado: O colapso do colonialismo indonésio em Timor-Leste" [Time is on Our Side: the Collapse of Indonesian colonialism in East Timor], Politica Internacional [Lisbon] 3, 21 (Spring 2000): 5-16.

Bung Karno dan Pemfosilan Pikiran-Pikiran Soekarno [Bung Karno and the Fossilization of Soekarno's Thinking]. Surabaya: Bamboe Roentjing, 2001. Reprinted in Indonesia 74 (October 2002): 1-19, citation above.

"Sibarani," introduction to Karikatur dan Politik: Augustin Sibarani, ed. Institut Studi Arus Informasi. Jakarta: Garba Budaya, 2001. vii-xii.

"Beberapa Usul demi Pembebasan Bahasa Indonesia" [Some Suggestions for the Liberation of the Indonesian Language], Tempo, December 31, 2001: 82-83.

"Politik Kamus" [The Politics of Dictionaries], Temp, March 17, 2002: 48-49. 
"l'Avenir de l'Indonésie," in États-nations, Multinations, Organisations Supranationales, ed. Michel Seymour, 429-44. Montreal: Liber, 2002. Reprinted in English as "The Future of Indonesia," in The Fate of the Nation-State, ed. Michel Seymour, 376-89. Montreal: McGill-Queens University Press, 2004.

“Naissance du Nationalisme,” L'Imaginaire National, October 2001: 32-33.

with Arief Djati, edited and annotated, Tjamboek Berdoeri [Kwee Thim Tjing], Indonesia dalem Api dan Bara [Indonesia in Flames and Embers]. Jakarta: Elkasa, 2004.

"Ong Muda" [The Young Ong], in Onze Ong: Onghokham dalam Kenangan, ed. David Reev, J. J. Rizal, and Wasmi Alhaziri, 53-61. Jakarta: Komunitas Bambu, 2007.

"Kham Niyom" [preface], in Satwikan, Phap reuang saeng khong Apichatpong Weerasethakul. Bangkok: Unknown Forces, 2007.

"Pret Pralaat: Prawatisat Narokphy" [Strange Spectres: A History of Hell], Aan 2, 2 (October 2009): 11-26.

with Kato Tsuyoshi, Yashigara han no soto e [Out from Under the Coconut Half-shell]. Tokyo: NTT, 2009.

with Arief Djati, Mendjadi Tjamboek Berdoeri [Becoming Tjamboek Berdoeri]. Jakarta: Komunitas bambu, 2010.

\section{Interviews}

Anil Ramdas, interviewer, "Lange Afstand, het verlichte nationalisme van Benedict Anderson," De Groene Amsterdammer, July 8, 1992.

"De bronnen van het nationalisme," De Groene Amsterdammer 118, 6 (April 20, 1994): 24-25 [excerpted from taped interview with Anil Ramdas].

Ben Abel, interviewer, "A Javanese King Talks of His End," Inside Indonesia 54 (AprilJune 1998): 16-17.

"Revolusi Pemuda" [interview], in Mencari Demokrasi [Seeking Democracy], ed. F. X. Baskara and T. Wardaya. Jakarta: Institut Studi Arus Informasi, 1999. 1-50.

Cynthia Foo, "Interview with Benedict Anderson," Invisible Culture 13 (2009), 4-21.

"Mega tidak seheibat Bung Karno" [Mega is not a Patch on Bung Karno], interview, Basis, March-April 2001: 13-17.

Scott Sherman, “A Return to Java,” Lingua Franca 11, 7 (October 2001).

Alexander Semyonov, interviewer, with tech. assist. Serguei Glebov, "Interview with Benedict Anderson-'We Study Empires As We Do Dinosaurs': Nations,

Nationalism, and Empire in a Critical Perspective," ab imperio, 3/2003: 57-93.

Filomeno Aguilar, Caroline Hau, Vicente Rafael, and Teresa Tadem, interviewers, "Benedict Anderson, Comparatively Speaking: On Area Studies, Theory, and ‘Gentlemanly’ Polemics,” Philippine Studies 59, 1 (March 2011): 107-39. 
Sheng Anfeng, "Minzuzhuyi yu zhi xue zhi lu" [The study of nationalism and the path of scholarship], Wenyi Yanjiu 2 (February 2015), 74-86.

Loh Kah Seng, "Southeast Asian Scholars at the Edge," CSEAS Newsletter 73 (Spring 2016), 43-45.

Wang Chaohua and Shen Sung-chiao, "Minzuzhuyi de qushi he yiuyou"

[Nationalism—-trends and problems], Sixiang 31 (September 2016), 243-58.

\section{Other}

with Sven-Erik Torhell. Den Föreställda Gemenskapen: Reflexioner Kring Nationalismens Ursprung Och Spridning. Historia Och Samhällsvetenskap. Göteborg: Daidalos, 1993. 